\title{
Agata Gniadkowska-Szymańska*
}

\section{ANALYSIS OF THE IMPACT OF TRADING LIQUIDITY ON THE DEVELOPMENT OF INVESTMENT TIME HORIZON ON THE EXAMPLE OF THE WARSAW STOCK EXCHANGE}

\begin{abstract}
The importance of liquidity has been acknowledged for a long time now. Liquidity is defined as the ease with which an asset can be converted into cash. A considerable number of studies investigated stock liquidity providing evidence that more illiquid stocks yield higher returns which include an illiquidity premium. According to Amihuda and Mendelson (1986b: 4348 ), a required rate of return on the shares (gross, i.e. after taking into account the cost of liquidity) should increase with increasing liquidity, but the marginal increase should decrease with an increasing investment horizon, thus decreasing the likelihood of premature termination of the investment. As a result, investors with different investment horizons may require different rates of return per unit of time from the same shares (Huang 2003: 104-129). Investor horizon is the time period for which an investor holds a stock. Most of the research conducted on investment horizon links it to liquidity, supporting the thesis that it is negatively related to liquidity. "Transaction costs and the holding periods for common stocks" written by Atkins and Dyl (1997: 309-325) is one of the first papers to investigate the effects of liquidity on holding period.

The aim of this study is to show the dependencies occurring between the phenomena of investment horizon and asymmetric information and the liquidity of shares of a company. horizon.

Keywords: asymmetric information, liquidity of shares, clientele effect, the investment
\end{abstract}

\section{INTRODUCTION}

The long-term success of any company depends on good strategy, good governance, high-value assets, the existence of demand for its products and services, and access to investment capital. Access to capital depends on many factors, but few investors would invest capital in a company which does not have a stable management structure. The Board and management must be responsible to shareholders for the company's results of its operations and administration of its assets.

The responsibility of the company's management is understood as the way in which those responsible for the daily management of the company are held accountable for the fulfilment of their duties to shareholders and other providers of the company's operating funds. Another important issue is information policy

* University of Lodz, Faculty of Economics and Sociology, Department of Economics of Industry and Capital Markets, agata.gniadkowska@uni.lodz.pl 
- this concerns the way in which the companies inform other interested parties (i.e. shareholders, potential investors, employees, supervisors and other parties concerned with matters of the company) about the activities they undertake. Despite the availability of Internet services, television and the developments in mobility, there remains a problem with shortage of information and/or poor transfer of information. It appears that this is connected to the phenomenon of asymmetric information, i.e. the situation whereby one side has much more information than the other. (Forlicz 1996: 166). On capital markets, efforts are made to minimize possible information asymmetries or to ensure, as far as possible, equal access to information for all market participants. Therefore, stock exchanges lay down strict disclosure obligations, according to which companies must provide the market with a lot of current information on their activities. ${ }^{1}$ But asymmetry always remains due to the fact that people working in the company will know about important events earlier than the market, which is why misuse of such 'inside' information is expressly forbidden, punished and prosecuted, this is called insider trading.

Investors can be divided into groups. The first group appreciates current income, hence they prefer the companies to pay out a high percentage of their profits. These investors are usually taxed low. The second group of investors are the wealthy shareholders who do not need current income from investments. They are motivated to acquire the shares with a low, or even zero payout ratio. They prefer reinvestments, i.e. that possible dividend payments are invested in the company after the payment of the income tax. Each separate group of investors may be called the 'clientele'. Hence the phenomenon that stems from the fact that a company's shares are owned by different groups of investors with different views on income from dividends and the resulting tax differences is referred to as the 'clientele effect'(Ross, Westerfield, Bradford 1999: 585-586). The concept of 'investment horizon' should also be noted here. Every investor has their own preferences for a particular period in which they want to invest their surplus cash. Not all financial instruments are subject to the same tax rates, hence the clientele effect may have an impact on the length of the investment. According to Amihuda and Mendelson (1986b: 43-48), a required rate of return on the shares (gross, i.e. after taking into account the cost of liquidity) should increase with increasing liquidity, but the marginal increase should decrease with an increasing investment horizon, thus decreasing the likelihood of premature termination of the investment. As a result, investors with different investment horizons may require different rates of return per unit of time from the same shares (see: Huang 2003: 104-129; Chung, Wei 2005: 239-249;

${ }^{1}$ Directive 2004/109/EC of the European Parliament and of the Council of 15 December 2004 on the harmonisation of transparency requirements in relation to information about issuers whose securities are admitted to trading on a regulated market and amending Directive 2001/34/EC. 
Gaspar, Massa, Matos 2005: 135-165). Investor horizon is the time period for which an investor holds a stock. Most of the research conducted on investment horizon links it to liquidity supporting the thesis? that it is negatively related to liquidity. "Transaction costs and the holding periods for common stocks" written by Atkins and Dyl (1997: 309-325) is one of the first papers to investigate the effects of liquidity on holding period. Further research confirmed that short-term investors prefer to invest in more liquid assets since they cannot afford the transaction costs of assets that are more illiquid. On the contrary long-term investors who trade less frequently can afford higher transaction costs and hold more illiquid stocks.

Beber, Driessen and Tuijp (2012) developed a new asset pricing model with heterogeneous horizon and stochastic transactions cost. The paper bridges the two papers from Amihud and Mendelson (1986b: 43-48) and Acharya and Pedersen (2005: 375-410) since the first one assumes that there are heterogeneous horizon investors but transaction costs are constant while the second assumes that although stochastic, transaction costs include only homogenous investors. Their results support the thesis that short-term investors prefer to invest in more liquid assets since they cannot afford the transaction costs of assets that are more illiquid. On the contrary long-term investors who trade less frequently can afford higher transaction costs and hold more illiquid stocks.

Chella, Ellul and Giannetti (2013: 1607-1648) conclude that during market turmoil short-term investors sell more than the long-horizon investors, due to the fact that short-term investors rely more on the short-term gains, hence when they see a turmoil coming they fear the possible stock price declines and thus they start selling immediately. Consequently, this leads to a more severe price drops which reveals that stock prices in periods of market shocks are driven by the investor horizon

The aim of this study is to show the dependencies occurring between the phenomena of investment horizon and asymmetric information and the liquidity of shares of a company.

\section{THE STUDY SAMPLE}

The study was conducted on a group of companies listed on the Warsaw Stock Exchange in the period of 31.01.2000-31.12.2012. The study selected companies that met all the following conditions:

- were listed on the Warsaw Stock Exchange in the period considered,

- belonged to WIG

- listing of their shares took place on a continuous basis (until January 2013) 
- the Reuters database contained their share price at the end of each of the 156 analyzed months. ${ }^{2}$

In this way, I was able to select 100 companies meeting the abovementioned criteria. Data on spreads came from the official website of the Warsaw Stock Exchange, while price data came from the Reuters platform. Prices have been adjusted for capital changes of types such as changes in subscription rights, dividends and splits. The study was carried out first based on monthly data calculated based on the prices of the last day of each month, then quarterly data calculated based on the prices of the last day of each quarter, and then annual data calculated based on the prices of the last day of each year. As the rate of return on risk-free assets I selected Wibor.

\section{METHODOLOGY}

The aim of this study is to show the dependencies occurring between the phenomena of investment horizon and asymmetric information and the liquidity of shares of a company.

The research methodology used is similar to that described by Amihuda and Mendelson (1986b: 43-48) in their work "Liquidity and Stock Returns". For the study, each year the companies in the sample were divided into ten portfolios of ten stocks each, depending on the average value of the average spread in the year. The influence of the spread on the rate of return was studied for the years 2004-2012, while the beta factor necessary to determine the systematic risk of shares was calculated based on 60 monthly returns, hence the earliest used data on rates of return covered the year 2000. For each of the years 2004-2012 portfolios were constructed based on the criterion of the average value of the spread in the year (these portfolios consisted of ten shares of spread, from the highest to the lowest spread). In addition, individual companies were allocated to one of six groups based on market capitalization in the previous month. Whenever the number of securities was not exactly divisible by six, the remaining securities were assigned to the lower market capitalization groups. In this way the group containing small capitalization companies may have a maximum of one more advantage than well-capitalized groups. Each of the six groups are divided into portfolios of high and low, compared to the spread.

Then the beta coefficient was calculated for each of the portfolios. The calculations were conducted using the method of least squares (OLS): the dependent variable was the surplus average monthly rate of return on the

\footnotetext{
${ }^{2}$ Only eight companies were eliminated as a result of the last criterion.
} 
portfolio, ${ }^{3}$ the surplus explanatory variable was the average rate of return on the WIG for 60 months $^{4}$ (five years), prior to the analysed year and including that year $(T-4$ to $T$, and $T \varepsilon(2004,2012))$. As the rate of return on risk-free assets I selected Wibor (after conversion to the monthly data and annual data).

Due to the use of the least squares method for calculating beta coefficients, the calculated coefficients were also tested for autocorrelation and heteroskedasticity. Durbin-Watson test doesn't, in most cases, reject the hypothesis of the absence of autocorrelation. This hypothesis can be rejected only for $13 \%$ of all models. Due to the estimation of a large amount of regression ${ }^{5}$ it is difficult to correct each of the equations so as to eliminate the problem of autocorrelation in $13 \%$ of all cases. It was therefore decided to leave the results unchanged, with the proviso that it may be a source of potential load test results. White test (White 1980: 817-838) on the stability of the variance indicates that the hypothesis of constant variance of the random component can be rejected for $9.11 \%$ of the total equation - although it is not. This value is negligible ${ }^{6}$, but these are relatively small fractions of all performed regressions. The high number of constructed regressions prevents the adjustment of each potentially loaded equation. Moreover, the load in the tested sample of estimates is relatively small. Therefore, it has been decided to leave the results in the previously obtained form.

Spread may not be the best measure of liquidity (Aitken, Comerton-Forde 2003: 45-59). It can also only be a determiner of the holding period of capital assets (Atkins, Dyl 1997: 309-325). However, the study was based on the assumption that the spread is an adequate measure of liquidity. As for the duration of the investment, the survey covers only variables such as the spread, beta ratio and market capitalization as variables defining possible conditions. The use of spread as the cost of liquidity appears to be justified because it was used by Atkins and Dyl (1997: 309-325) as an independent variable in their study of the clientele effect. Amihud and Mendelson (1986b: 43-48) argued, however, that the clientele effect is achieved through mechanisms that drive

\footnotetext{
${ }^{3}$ Surplus return is understood as the difference between the return on a given instrument and the rate of return on risk-free assets.

${ }^{4}$ The portfolios for 2004 were 59 months, due to the start of the test at the end of January 2000 , and thus such portfolios had one observation (months return) fewer.

${ }^{5}$ It was carried out on about 15300 estimates of the regression line.

${ }^{6}$ Due to the large number of successful estimations of the regression line (about 15300 estimates) it is physically difficult to correct occurring in these cases, estimates potentially loaded by the occurrence of heteroscedasticity or autocorrelation. However, as evidenced by other studies, for example Brzeszczyński, Gajdka, Schabek (2011) and the analysis carried out on the sample of estimates potentially loaded by the presence of heteroskedasticity or autocorrelation (sample for the year 2008), these loads do not constitute significant error (from a few to less than 20 percent of the estimate) and they may not significantly affect the conclusions of the study. However, they remain a potential source of load results.
} 
investor indifference between assets. Under equilibrium conditions the asymmetry of information, the time horizon of investment, or transaction costs caused the expected rate of return on the shares (gross) to undergo growth with the increase in spread. For example, if it is expected that two shares will generate the same stream of cash at the same risk to shareholders, but are characterized by varying spreads, more investors will buy the share with the lesser spread, with the result that the rate of return from this purchase will be relatively lower. In contrast, the higher the spread, the higher the rate of return. This type of behaviour provides a constant balance in asset prices. A return to equilibrium systems may be dependent on feedback mechanisms, which makes it difficult to determine the direction of causality. We can therefore expect that it will be difficult to determine causality with respect to the clientele effect. This argument is supported by the studies of Atkins and Dyl (1997: 309-325), which used the Granger causality test to determine its direction.

Just as in the study of the relationship between the spread and the expected rate of return for investors, variables such as the spread, beta ratio, the capitalization of the company were subjected to linear regression in relation to the holding period of the following month. The regression equation is as follows:

$$
\ln \left(H P_{p T+1}\right)=\alpha+\theta_{1} \beta_{p T}+\theta_{2}\left(\operatorname{Cap}_{p T}\right)+\theta_{3} \ln \left(S_{p T}\right)+\varepsilon_{p T}
$$

where:

$H P_{p T+1}$ - refers to the average holding period of a secure i / calculated as shares in issue divided by the trading volume,

$\mathrm{Cap}_{p T}$ - refers to the monthly capitalization of the portfolio,

$S_{p T}$ - refers to the average monthly spread of the portfolio;

$\varepsilon_{p T}-$ refers to the rest of the equation.

Atkins and Dyl (1997: 309-325) in their studies presented evidence that the relationship between the spread and the holding period cannot be determined immediately, because these two variables can be set simultaneously. To work around this problem, they use a two-stage regression, where the spread in the current period is determined taking into account the spread of the previous year, as well as the variance and the market capitalization of the previous month. Such an approach, however, requires that portfolios were maintained at a constant level, which does not fit into the methodology of this study. Hence the results of these regressions cannot be used to assess causality; it merely indicates the extent to which the holding period of the investment of the coming month can be used to predict the relative spread of the current month. Atkins and Dyl (1997: 
309-325) state that there is a significantly positive impact for both the spread and market capitalization and significantly negative impact on the rate of return on variance. Atkins and Dyl (1997: 309-325) studied the variance, in contrast to the beta ratio, but their proposed argument that high volatility (and therefore high volatility and high beta) drives high turnover can also be applied to the beta ratio. For this reason, the expected beta ratio is negative, or in other words a higher beta value should lead to a shorter holding period of assets by investors.

\section{THE RESULTS OF THE STUDY}

Amihud and Mendelson (1986b: 43-48) show in their study that the required rate of return on shares is expected to increase with increasing liquidity, but the marginal increase should decrease with increasing investment horizon, decreasing the likelihood of premature termination of the investment. In contrast, as shown in many studies (see: Amihud, Mendelson 1986b: 43-48; Alles, Athanassakos 2006: 138-52; Choi, Mukherji 2010: 1-6). the holding period of the investment affected to a significant extent the rate of return on the investment. Hence, using the methodology described by Atkins and Dyl (1997: 309-325) in their work "Transaction costs and the holding periods for common stocks," I first checked the relationship between the average holding period of the investment and the systematic risk, measured as beta ratio, company size measured as capitalization and the spread of the collected data for obtaining the results, as described in Table 1 . For the calculations, instead of the average spread I used the logarithm of the average spread calculated from the average monthly spread of each portfolio.

As can be seen from the calculations presented in Table 1 performed on quarterly and annual data, the estimation of a parameter relating to the spread is positive and statistically significant at the 0.05 level. From these calculations it can be concluded that there exists a relationship between the average holding period of the investment and the average spread calculated with respect to annual and quarterly data. In contrast, the parameters set out in Parts A and B of Table 1 estimated for beta ratio and capitalization are also statistically significant, which means that the beta ratio and company size, measured as capitalization affect the formation of the rate of dividends on the shares quarterly and annual data. In addition, dummies for the differences in the average holding period of the investment in individual years in case of annual and quarterly data are statistically insignificant, meaning they have no influence on the shape of the average holding period of the investment. 
Table 1. Estimated model parameters and corresponding values of $p$-value and statistics $t$-student

\begin{tabular}{|c|c|c|c|}
\hline & Estimators & $\begin{array}{l}\text { Statistics } \\
t \text {-student }\end{array}$ & $p$-value \\
\hline \multicolumn{4}{|c|}{ ANNUAL DATA } \\
\hline \multicolumn{4}{|c|}{$\mathrm{A}$} \\
\hline free term & -0.020461 & -4.03346 & 0.000127 \\
\hline $\log ($ spread $)$ & 0.010058 & 4.77230 & 0.000008 \\
\hline capitalization & 0.000001 & 3.04930 & 0.003132 \\
\hline beta & -0.000021 & -0.63220 & 0.529107 \\
\hline 2004 & 0.002414 & 1.30579 & 0.195462 \\
\hline 2005 & 0.001237 & 0.69024 & 0.492094 \\
\hline 2006 & 0.000059 & 0.03377 & 0.973147 \\
\hline 2007 & 0.002711 & 1.51736 & 0.133218 \\
\hline 2008 & 0.002236 & 1.18638 & 0.239072 \\
\hline 2009 & 0.002058 & 1.14060 & 0.257525 \\
\hline 2010 & 0.001477 & 0.83558 & 0.405941 \\
\hline 2011 & 0.002689 & 1.55072 & 0.125018 \\
\hline \multicolumn{4}{|c|}{ QUARTERLY DATA } \\
\hline \multicolumn{4}{|c|}{$\mathrm{B}$} \\
\hline free term & -0.007671 & -2.12384 & 0.034397 \\
\hline capitalization & 0.000000 & 1.97985 & 0.048517 \\
\hline beta & -0.001376 & -2.90537 & 0.003906 \\
\hline $\log ($ spread $)$ & 0.007098 & 5.72217 & 0.000000 \\
\hline 2004 & -0.002289 & -1.54444 & 0.123401 \\
\hline 2005 & -0.002724 & -1.86697 & 0.062757 \\
\hline 2006 & -0.002752 & -2.24782 & 0.025221 \\
\hline 2007 & -0.001112 & -0.94521 & 0.345214 \\
\hline 2008 & 0.001332 & 1.04647 & 0.296080 \\
\hline 2009 & 0.000540 & 0.43774 & 0.661850 \\
\hline 2010 & 0.000596 & 0.49181 & 0.623169 \\
\hline 2011 & 0.001357 & 1.14451 & 0.253210 \\
\hline \multicolumn{4}{|c|}{ MONTHLY DATA } \\
\hline \multicolumn{4}{|c|}{$\mathrm{C}$} \\
\hline free term & -0.000440 & -0.16192 & 0.871401 \\
\hline $\log ($ spread $)$ & 0.006112 & 7.11868 & 0.000000 \\
\hline beta & -0.007144 & -4.97409 & 0.000001 \\
\hline capitalization & 0.000000 & 2.88519 & 0.003992 \\
\hline 2004 & -0.000374 & -0.35582 & 0.722051 \\
\hline 2005 & -0.001800 & -1.83725 & 0.066456 \\
\hline 2006 & -0.003261 & -3.34643 & 0.000848 \\
\hline 2007 & -0.001015 & -1.02463 & 0.305775 \\
\hline 2008 & 0.001408 & 1.35817 & 0.174703 \\
\hline 2009 & -0.000750 & -0.75163 & 0.452440 \\
\hline 2010 & 0.000300 & 0.29422 & 0.768652 \\
\hline 2011 & 0.001067 & 1.06579 & 0.286764 \\
\hline
\end{tabular}

Source: authors own calculations. 
The fit of the model estimated on quarterly data to the actual data as measured by the coefficient $R^{2}$, is 0.117 ; adjusted $R^{2}$ is 0.15 ; while the average regression error (standard error of estimation) is 0.00519 . The fit of the model estimated using annual data to the actual data as measured by the coefficient $R^{2}$, is 0.30 ; adjusted $R^{2}$ is 0.20 ; while the average regression error (standard error of estimation) is 0.0038 .

As is apparent from the data shown in Table 1, Part C, the data used to estimate a parameter relating to spread is positive and statistically significant at the 0.05 level. Therefore, the hypothesis was confirmed that there is a relationship between the average holding period of the investment and liquidity measured by the spread, i.e. between an increase in the average holding period of the investment and an increase of the spread. To be precise, the research confirms that the regression coefficients are statistically significant. Other variables in the study, which include the beta ratio and the size of the company measured as capitalization, also have an impact on the development of holding period of investments in shares. But the dummies taking into account the differences in the average holding period of investments in individual years are in this case not statistically significant. Adapting the model to real data, measured by the coefficient $\mathrm{R}^{2}$ is 0.103 ; adjusted $R^{2}$ is 0.094 ; while the average regression error (standard error of estimation) is 0.0075 .

\section{CONCLUSIONS}

A number of previous studies have examined the relationship of liquidity and investor holding period mostly cross-sectionally and for a considerable number of stocks. Amihud and Mendelson (1986b: 43-48) were some of the first to argue that assets with higher spreads are allocated to portfolios with higher holding period. Atkins and Dyl (1997: 309-325) find a positive relationship between illiquidity and holding period. All these studies suggest that when a stock is more illiquid then it is held by an investor who has a higher investment horizon since these investors don't trade frequently and can afford to keep the stock for a longer period of time. Vovchak (2014) tests the reverse relationship between liquidity and time horizon using panel data, various liquidity measures and lagged horizon and obtains, as well, a negative relationship between these two variables since his proxy for investment horizon measures the inverse of the actual horizon.

The study described by Atkins and Dyl (1997: 309-325) in their work "Transaction costs and the holding periods for common stocks" was carried out to verify the relationship between the average holding period of the investment, and thus also the rate of return on shares and systematic risk measured by the 
beta factor, the size of the company as measured by market capitalization, and the average size of the spread. The analysis is based on share portfolios constructed according to the methodology presented by Amihud and Mendelson (1986b: 43-48).

In the case of analyzing liquidity as a medium-sized spread on the monthly, quarterly and annual data it turned out that liquidity was expressed as a spread affected by the development of the average holding period of investment of the analyzed shares. However, for all presented periods, the parameters estimated for the zero-one variables which take into account differences in the average, secure holding period of the investments in individual years, are not statistically significant, meaning they have no influence on the average holding period of the investment, and thus also neither on the rate of return on shares.

In the case of the Polish Stock Exchange, the presented studies can be confirmed by the study presented by Atkins and Dyl (1997: 309-325) in their work "Transaction costs and the holding periods for common stocks". The same is also true for the results presented by Amihud and Mendelson (1986b: 43-48).

For the authorities monitoring capital markets and the financial system, the research results may shed some light on the issue of liquidity of the entire Polish capital market. This would allow for appropriate steps to be taken to increase the liquidity. Also, in the context of capital valuation, which is dominated by the CAPM model associated approach, these results can be used for more accurate and broader valuation, taking into account companies' characteristics and sensitivities identified in the research.

\section{BIBLIOGRAPHY}

Acharya V., Pedersen L.H. (2005), Asset pricing with liquidity risk, "Journal of Financial Economics", vol. 77(2), p. 375-410.

Aitken, M., Comerton-Forde C. (2003), How should liquidity be measured?, "Pacific-basin Finance Journal", No. 11(1), p. 45-59.

Alles L., Athanassakos G. (2006), The effect of investment horizons on risk, return and end-ofperiod wealth for major asset classes in Canada, "Canadian Journal of Administrative Sciences", vol. 23, p. 138-152.

Amihud Y. (2002), Illiquidity and stock returns: cross-section and time-series effects, "Journal of Financial Markets", No. 5, p. 31-56.

Amihud Y., Mendelson H. (1986a), Asset Pricing and a Bid-Ask Spread, "Journal of Financial Economics", vol. 17, p. 223-249.

Amihud Y., Mendelson H. (1986b), Liquidity and Stock Returns, "Financial Analysts Journal", vol. 42, No. 3, p. 43-48.

Amihud Y., Mendelson H. (1989), The effects of beta, bid-ask spread, residual, risk and size on stock returns, "Journal of Finance", No. 44, p. 479-486.

Atkins, A.B., Dyl, E.A. (1997), Transaction costs and the holding periods for common stocks, "The Journal of Finance", No. 52(1), p. 309-325. 
Beber, A., Driessen J., Tuijp P. (2012), Pricing liquidity risk with heterogeneous investment horizons, working paper, Cass Business School.

Brigham E.F., Gapenski L. C. (2000), Zarzadzeni Finansami, PWE, Warszawa.

Cella C., Ellul A., Giannetti M. (2013), Investors' horizon and the amplification of market shocks, "Review of Financial Studies", No. 26, p. 1607-1648.

Chang Y.Y., Faff R., Hwang C.-Y. (2010), Liquidity and Stock Returns in Japan: New Evidence, "Pacific-Basin Finance Journal", No. 18(1).

Choi P., Mukherji S. (2010), Optimal portfolios for different holding periods, "Journal of Business and Economics Research", vol. 8, p. 1-6.

Chung S., Wei P. (2005), The relationship between bid-ask preads and holding periods: The case of Chinese A and B shares, "Global Finance Journal”, No. 15, p. 239-249;

Dębski W. (2010), Rynek finansowy i jego mechanizmy, PWN, Warszawa.

Directive 2004/109/EC of the European Parliament and of the Council of 15 December 2004 on the harmonisation of transparency requirements in relation to information about issuers whose securities are admitted to trading on a regulated market and amending Directive 2001/34/EC.

Forlicz S. (1996), Mikroekonomiczne aspekty przeptywu informacji między podmiotami rynkowymi, Wydawnictwo Wyższej Szkoły Bankowej, Poznań.

Gajdka J., Gniadkowska A., Schabek T. (2010), Plynność obrotu a stopa zwrotu z akcji na Gietdzie Papierów Wartościowych w Warszawie, Uniwersytet Ekonomiczny w Poznaniu, "Zeszyty Naukowe" nr 142.

Gajdka J., Walińska E. (1998), Zarządzanie finansowe - teoria i praktyka, Warszawa, Fundacja Rozwoju Rachunkowości w Polsce.

Gaspar J.M., Massa M., Matos P. (2005). Shareholder investment horizons and the market for corporate control, "Journal of Financial Economics", No. 76, p. 135-165.

Huang, M. (2003), Liquidity shocks and equilibrium liquidity premia, "Journal of Economic Theory", No. 109, p. 104-129.

Litzenberger R., Ramaswamy K. (1979), The Effects of Personal Taxes and Dividends on Capital Asset Prices, "Journal of Financial Economics".

Pastor L., Stambough R. (2003), Liquidity risk and expected stock return, "The Journal of Political Economy", No. 111(3).

Ross S.A., Westerfield R.W., Bradford D.J. (1999), Finanse przedsiębiorstw, Dom Wydawniczy ABC, Warszawa.

Vovchak V. (2014), Liquidity and Investment Horizon, "Swiss Finance Institute Research Paper", No. $14-02$.

White H., 1980, A Heteroskedasticity-Consistent Covariance Matrix Estimator and a Direct Test for Heteroskedasticity, Econometrica, No. 48(4), p. 817-838.

www.gpw.pl, [as of 16.08.2012].

www.gpwinfostrefa.pl, [as of 11.12.2014].

www.knf.gov.pl, [as of 16.08.2012].

Agata Gniadkowska-Szymańska

\section{ANALIZA WPLYWU PLYNNOŚCI OBROTU NA KSZTALTOWANIE SIE HORYZONTU CZASOWEGO INWESTYCJI NA PRZYKLADZIE GIEEDY PAPIERÓW WARTOŚCIOWYCH W WARSZAWIE}

Streszczenie. Przez płynność aktywów na rynku finansowym rozumiane są zazwyczaj: koszt oraz łatwość, z jaką poszczególne rodzaje aktywów mogą być zamienione na środki pieniężne, czyli mówiąc najprościej sprzedane po cenie aktualnie dostępnej na rynku. W literaturze przedmiotu można znaleźć wiele badań, które potwierdziły, że płynność wywiera istotny wpływ na ceny akcji i ich stopy zwrotu. 
Każdy inwestor ma swoje preferencje dotyczące okresu, na jaki chce zainwestować posiadane nadwyżki gotówki. Według Amihuda i Mendelsona wymagana stopa zwrotu z akcji (po uwzględnieniu kosztów związanych z płynnością) powinna wzrastać wraz ze wzrostem płynności danej akcji, jednak krańcowy przyrost winien zmniejszać się wraz z wydłużaniem horyzontu czasowego inwestycji oraz zmniejszaniem prawdopodobieństwa przedterminowego zakończenia inwestycji. W rezultacie inwestorzy o różnych horyzontach czasowych inwestycji wymagać mogą różnej stopy zwrotu na jednostkę czasu od tych samych akcji. Horyzont czasowy inwestycji jest okresem, w którym inwestor posiada akcji. Większość badań przeprowadzonych z uwzględnieniem horyzontu czasowego inwestycji łączy go z płynnością danego papieru wartościowego w taki sposób, że horyzont czasowy inwestycji jest ujemnie powiązany z płynnością. Atkins i Dyl są jednymi z pierwszych, którzy zbadali wpływ płynności na okres inwestowania.

Celem przedmiotowego badania jest pokazanie zależności zachodzącej pomiędzy horyzontem czasowym a płynnością akcji danej spółki.

Słowa kluczowe: płynność akcji, horyzont czasowy inwestycji, efekt klienteli, asymetria informacji. 